\title{
DEVELOPMENT OF FLOOD TRACKING TECHNIQUE FOR FLOOD DISASTER MANAGEMENT IN URBAN AREAS
}

\author{
DONG HO KANG ${ }^{1}$, SUK HO LEE ${ }^{2} \&$ BYUNG SIK KIM ${ }^{1}$ \\ ${ }^{1}$ Department of Urban and Environmental Disaster Prevention Engineering, Kangwon National University, \\ Republic of Korea \\ ${ }^{2}$ Risk Management Research Department, UNO Co., Ltd., Republic of Korea
}

\begin{abstract}
The change in precipitation due to climate change has induced local and torrential rainfalls. As a result, protected lowlands have an increased risk of damage caused by river inundation and subsequent flooding. Thus, it is necessary to have the technology to predict the damage due to flooding in a protected lowland. This study developed a distributed flood and inundation model called Simplified Inundation Model (SIMOD) to simulate a flooding path for identifying how flooding caused by river embankment's breakage is inundated and spread in a protected lowland. Two methods were applied to simulate a flood path: the multiple flow direction method (MFDM) and the flat-water assumption (FWA) method. Virtual scenarios were set to calculate an inundation range over time in the Seongseoje, located downstream of the Geumho river, and evaluate the model. In addition, the urban inundation analysis was executed using the SIMOD. The results were compared to results from using the commercial inundation analysis two-dimensional flood routing model (FLO-2D) to verify the model's applicability. The study applied the digital elevation model (DEM) terrain data for conventional flooding analysis and digital surface model (DSM) terrain data to represent urban building groups and road distribution. The 24-hour simulation was done less than 7 minutes using the SIMOD, and the difference in flooded areas was less than 20\% compared to FLO-2D. Moreover, the study identified the need for topographical data using DSM for urban areas, as the analysis proves the influence of roads and buildings on flooding.

Keywords: simplified inundation model (SIMOD), two-dimensional flood routing model (Flo-2D), multi direction method (MDM), flat-water assumption (FWA).
\end{abstract}

\section{INTRODUCTION}

Global weather and water-related disasters caused by climate change have increased events of flood and drought. The extreme weather phenomenon called "super El Niño" continues to bring record-breaking rainfalls and consequential damages to the United States and Latin America. These severe rainfall events have submerged some urban areas in the mid-western region of the United States by overflowing the Missouri and Mississippi Rivers. Similarly, Paraguay in Latin America has experienced its worst flooding due to this weather phenomenon. The La Niña phenomenon, El Niño's reverse and equally extreme weather phenomenon, increases rainfall in the western Pacific regions, directly impacting the flood and drought South Korea has been experiencing. The country experienced severe drought successively in 2014 and 2015 and is currently suffering from drought. Damages caused by this phenomenon may worsen with floods in a few years due to the increased severity and frequency of extreme precipitation and drought over time [1]. Moreover, the current design of South Korea's drainage-related infrastructure did not consider extreme weather phenomena because its frequency analysis was based on the assumption of stationarity. Thus, the design flood was calculated using the frequency analysis considering the nonstationarity of extreme weather characteristics [2].

The design criteria for levees of main rivers in Korea were structured to protect against 100-year floods. However, considering the extreme weather characteristics of interchanging severe rain and drought, flooding would be less frequent but more severe. Furthermore, 
because of extreme precipitation, the possibility of floor damage in protected lowlands (urban areas) increases due to possible overflow and levee breaches. In particular, a flood stage increases rapidly in urban streams with a short travel time during torrential rainfalls, putting stream facilities, such as roads, bridges, and buildings in protected lowlands, at a very high risk of damage [3]. Thus, it is necessary to cope with flooding due to extreme weather by establishing an emergency action plan (EAP) at urban streams. A highly reliable model is needed to predict flooding and set up an appropriate measure.

The stormwater management model (SWMM), two-dimensional flood routing model (FLO-2D), and MIKE FLOOD are available as multi-dimensional flood models to simulate flooding. For the SWMM, it takes a long time to develop baseline data, such as storm sewer networks. Likewise, developing baseline data, such as river network configuration and boundary conditions, is time-consuming using MIKE FLOOD. For the FLO-2D model, its simulation time takes much longer as it requires advanced hardware resources and technical skills to develop a high-performance real-time forecast system in a short period using a multi-dimensional flooding model [4]. Thus, it is necessary to create a time-efficient and cost-effective method by simplifying a complex model.

In this study, a distributed flood and inundation model called the Simplified Inundation Model (SIMOD) was developed to simulate a flood routing path in a protected lowland (urban area). The digital elevation model (DEM) or digital surface model (DSM) uses terrain data and simple hydrological data, such as inflow floods. This model was developed to express a flood routing path over time, which has the advantage that it can produce results within a relatively short simulation time, around 10 minutes. The flood routing path is simulated in densely populated urban facilities of Daegu Metropolitan City following a levee (Seongseoje) break and Geumho river basin overflow. A comparative analysis with the commercial FLO-2D model was conducted to verify the developed model's applicability.

\section{RESEARCH TREND}

The research trend in South Korea and overseas has changed from employing inundation analysis methods using various mechanisms in the past to using strategies applying inundation models easily and rapidly by simplifying models in recent years [5]. Simulated flooding considering land use, buildings, narrow flow path, and changes in underground rainwater drainage to model the runoff in a flood plain in urban areas. Similarly, Pathirana et al. [6] developed a two-dimensional (2D) urban inundation model and linked the model with EPA-SWMM5, which was a one-dimensional (1D) drainage network model. They also simulated urban inundation by simplifying the model's process using the spread and dynamic models. In addition, Nanshan et al. [7] developed an integrated flood and inundation simulation model to predict and evaluate the flood risk using friction parameters to estimate flow data and damage area to provide terrain data, DEM, and model's inflow and outflow boundary conditions. In addition, Yang, et al. [8] conducted a study on developing a real-time flood forecast system using a simplified model with DEM for flood routing in a protected lowland. Likewise, Liu et al. [9] developed and applied an efficient cellular automata model to simulate rainfall-runoff and flood-inundation process with extreme rainfall events. This model can simulate infiltration, runoff, and dynamic flow behavior.

Related studies in Korea were conducted mainly to analyze inundation in protected lowlands for EAP or flooding map creation [10]. Applied Preissmann's method to analyze flooding in a river by considering levee overflow and physical breakage characteristics and propagating the resulting flood wave was to a protected lowland. Their study used $1 \mathrm{D}$ and 
2D models for inundation analysis in a protected lowland. Subsequently, they developed a numerical analysis model to connect the areas between the stream channel and protected lowland where the two models can interact. In addition, they introduced a related equation for the analysis of submerging effect to accurately calculate the overflow from the river according to the water level rise in the protected lowland.

Lee and Yeon [11] performed an inundation analysis by hourly analyzing the inundation depth and area using XP-SWMM. A different investigation by Lee et al. [12] studied flood and levee collapse characteristics in the Jungnangcheon, a typical urban stream in Korea, to analyze the levee inundation due to torrential rainfall urban stream basins and the damage size due to inundation under various conditions spatiotemporally. Specifically, they analyzed unsteady stream flows and flooding in a protected lowland for each levee breach condition using the Flood Wave routing model (FLDWAV). The subcritical and supercritical flows, or mixed flows where two flow conditions were combined spatiotemporally, could be calculated using this model.

In addition, Park et al. [13] analyzed the inundation and flood based on levees' erosion and scour theory. Their analysis was done during the river levee collapse, changes in levee breakage width over time, estimation of inundation depth and area, and levee collapse while considering the change in river flow to predict the estimated damage caused by inundation. Moreover, they analyzed the water level in urban streams where a levee collapsed, the breach flow calculation, flood map creation, and inundation depth through the developed model. Similarly, Kim et al. [14] calculated a dam break outflow according to various dam collapse scenarios to prepare a method of flood inundation map, which was coupled with the 1D dam-break flood forecasting model (DAMBRK) for dam collapse and geographic information system (GIS). In addition, they compared the maximum flood stage with the right and left levee heights and calculated the peak flow, maximum flood stage, flood-wave travel time, and travel time at the maximum flood stage. Their study was done to show detailed flood inundation map preparation by water depth based on the hydraulic analysis of the river linked with the GIS. Conclusively, their study overcame the limitations of 1D hydraulic analysis models on the river had regarding the floodplain analysis. Moreover, Kim et al. [15] calculated a peak flood discharge over the collapse duration by simulating a virtual dam collapse during the probable maximum precipitation and simulated inundation time, shape, and area by collapse duration.

\section{THEORETICAL BACKGROUND}

Based on scenarios, the river inundation flow due to past floods can be generated in any arbitrary cell over time. The generated flow has different pathway directions following the downward slope that produces a flow direction slope and the upward slope that creates a reverse direction slope. The multiple flow direction method (MFDM) was used when the flow had a downward slope, while the flat-water assumption (FWA) was employed when the flow had an upward slope. Fig. 1 shows the SIMOD data processing and flow chart. In the MFDM, the total outflow was distributed to the lowest elevation cell among the adjacent eight cells of the inundation starting cell. In contrast, the total outflow was distributed to the neighboring cells when surrounding all eight cells of the inundation starting cell had a higher elevation than that of the starting cell. Thus, the flood at a specific time from the inundation starting cell is transferred to adjacent cells according to two algorithms, MFDM and FWA, explained in the following subsections. 


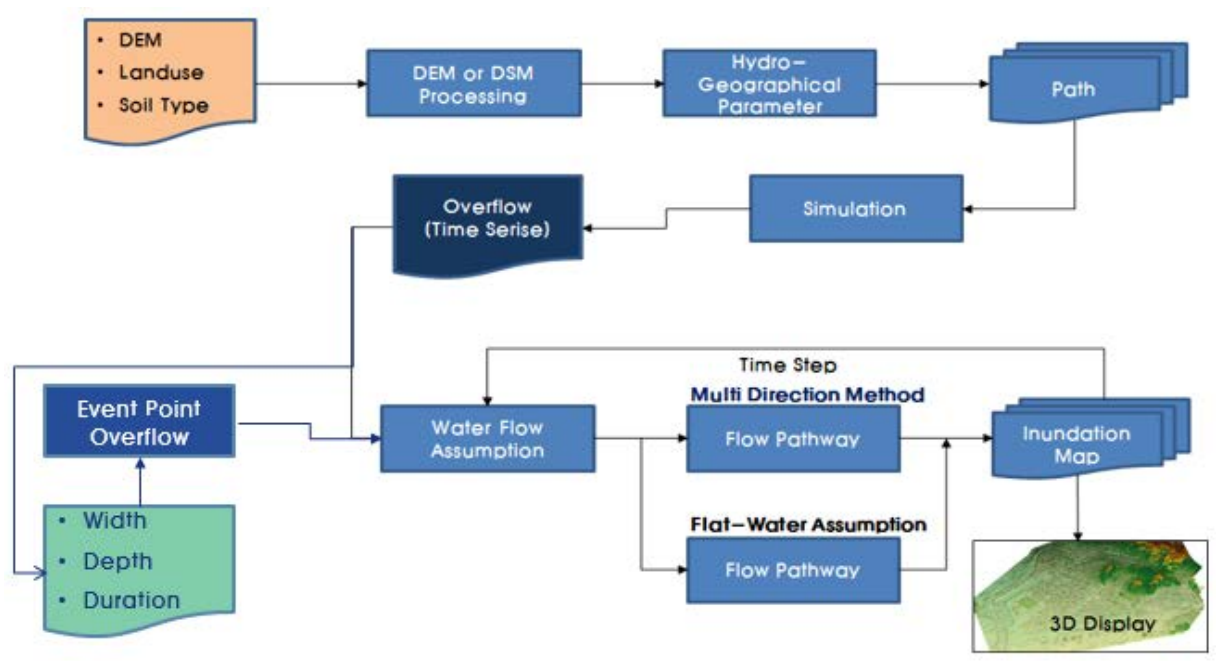

Figure 1: Flowchart of simplified inundation model (SIMOD).

\subsection{Multi-flow direction method}

The flood scenario determined the river flood flow. The river flood flow's starting cell was then established as the point at which the flood started. When the simulated flood began, the total outflow was distributed and transferred to adjacent cells. Previously, the singleflow direction method (SDM) was mainly used to distribute the flood discharge. In the SDM, the total outflow was distributed to adjacent cells using the D- 8 and D- $\infty$ methods, as shown in Fig. 2(a) and (b). The D-8 method distributes the total outflow to the lowest slope cell out of eight adjacent cells of the flood starting cell. In contrast, the D- $\infty$ method, proposed by Tarboton [16], determines the steepest downward slope of all eight adjacent cells as the flow direction angle, thereby creating one or two cells adjacent to the flow direction (Fig. 3(b)). Then, the water flow was distributed to one or two adjacent cells to the flow direction of their adjacent cells. In these two methods, the floodwater flows ultimately in a single direction. However, the flow directions may have many directions depending on the slopes. Accordingly, it is necessary to have a method that distributes the water flow to a cell whose elevation is lower than that of the starting cell.

The MFDM is a method that distributes the total outflow to downslope neighboring cells from the starting cell, where the elevation difference of all adjacent cells is weighted. Assuming that the lowest elevation difference is set to one, the total outflow is distributed differentially to adjacent cells whose elevation difference is lower than the lowest elevation difference according to the ratio of elevation difference. This process continues until the elevations of adjacent cells are higher than that of the starting cell when the distributed floodwater reaches the lowest elevation.

\subsection{Flat-water assumption (FWA)}

The FWA method, proposed by Yang et al. [4], follows the floodwater flow as it continues downward until it reaches and accumulates in the lowest elevation cell. Because of water 


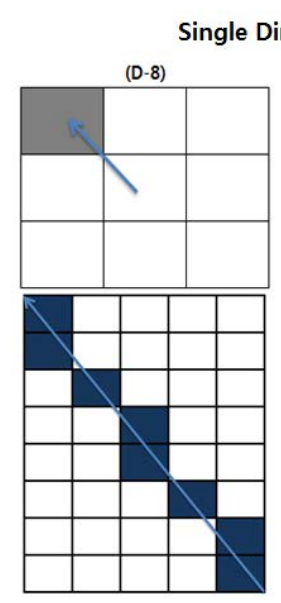

(a)

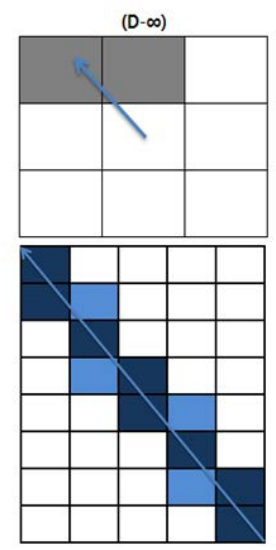

(b)

\section{Multi Direction Method}

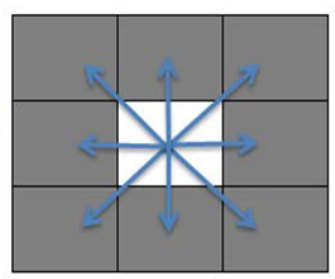

(c)

Figure 2: Flow distribution method.

(a)
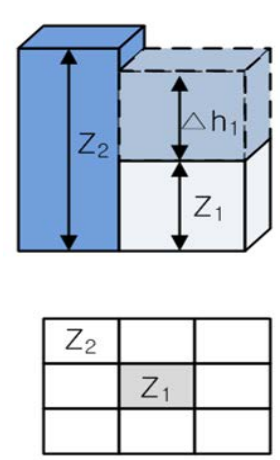

(b)
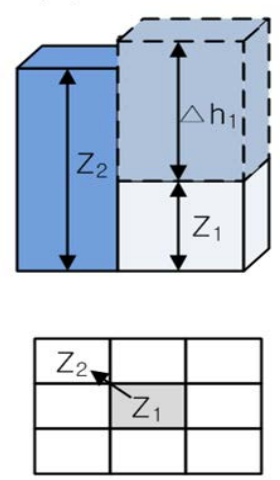

(c)
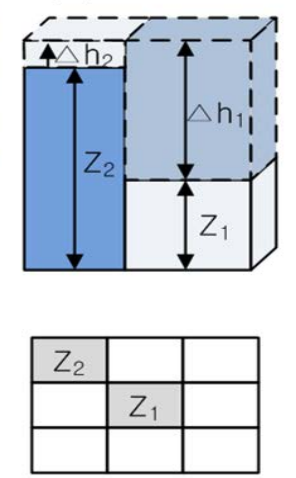

Figure 3: Water spreading using the flat-water assumption [8].

accumulation, elevation rank in the cell is equivalent to that of the adjacent cells; thus, the cell becomes the inundation starting cell where the total flow is accumulated. In Fig. 3(a), the water level in the Z1 cell increases until the water spreading condition [Z1 $+\Delta \mathrm{h} 1>\mathrm{Z} 2]$ is met. When the total outflow is added, Z2 should satisfy the flat-water assumption [Z1 + $\Delta \mathrm{h} 1=\mathrm{Z} 2+\Delta \mathrm{h} 2$ ] (Fig. 3(c)), and the flow of the cell is spread to neighboring cells according to this algorithm.

\section{TARGET AREA AND APPLICATION}

\subsection{Select of target area}

The use of SIMOD is most suited for areas with a nearby river and a levee of sufficient height, and where the influence of protected lowland facilities, such as buildings and roads, 
can be analyzed to apply the flood and inundation scenarios. Thus, as shown in Fig. 4, a levee (Seongseoje) located downstream of the Geumho river was selected as the study area.

The Geumho river basin includes a part of one metropolitan city, one province, three cities, two counties, seven districts, four towns, and 20 townships, such as Daegu Metropolitan City, Gyeongsan-si, Yeongcheon-si, Pohang-si, Chilgok-gun of Gyeongsangbuk-do. Its basin area is $2,092.42 \mathrm{~km}^{2}$ with a channel length of $116.0 \mathrm{~km}$. In the Geumho river basin, there are 52 regional tributary streams, including Jahocheon, Gochoncheon, Sillyeongcheon, and Sincheon, where the total stream length, including the Geumhho river, reaches 590.76 km [17].

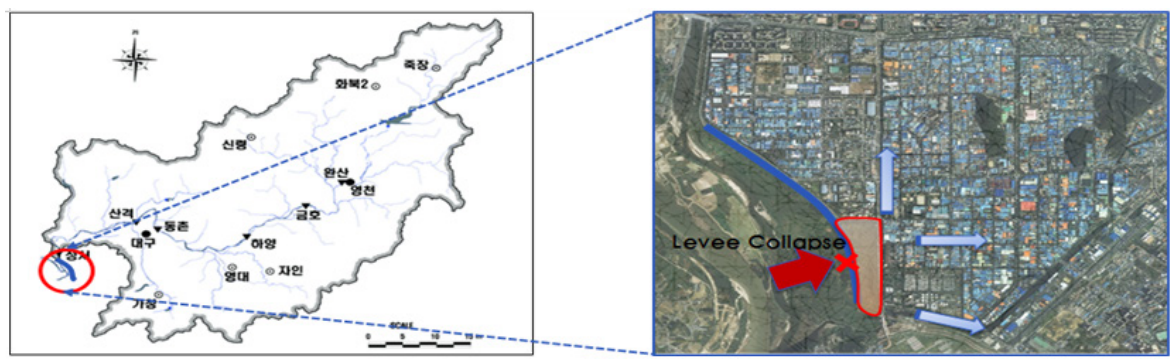

Figure 4: Location of target area and levee collapse.

\subsection{Construct of input data}

SIMOD requires two input data for simulations to be conducted, namely, inflow flood and terrain data. For the inflow flood, a virtual scenario was set where the flood overflew due to the Seongseoje levee collapse, as shown on the right side of Fig. 5. The inflow water was introduced to the protected lowland (industrial complex) beyond the flood-control reservoir. Fig. 6 shows the flow chart of inflow calculation.

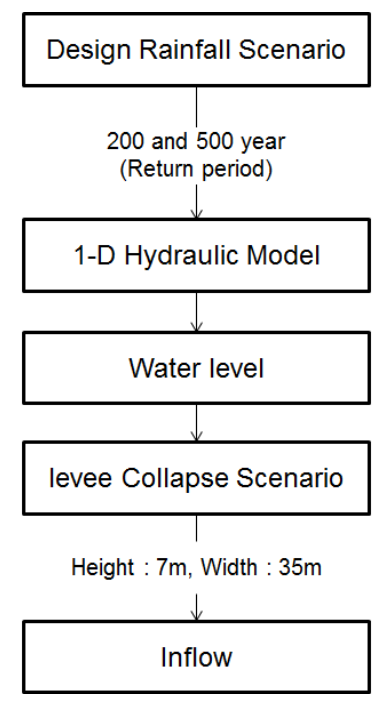

Figure 5: Flowchart for inflow calculation. 


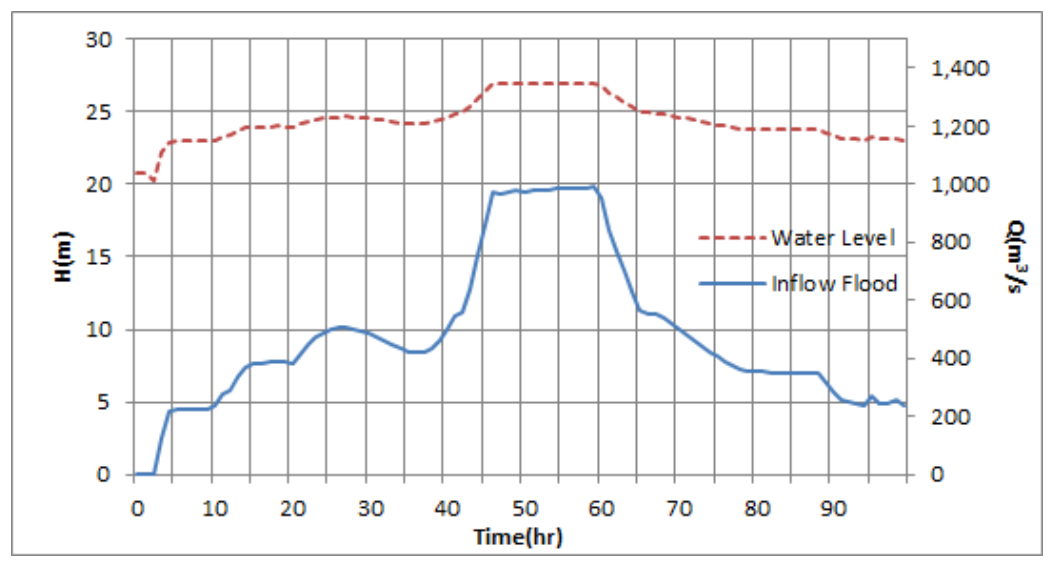

Figure 6: Water level and inflow flood.

The stream's water level was calculated based on heavy rainfall and typhoon scenarios made by the Technical Development Research Division of Integrated Safety Management for Waterside Structures based on Disaster Scenarios in Korea (Fig. 7). The levee collapse scenario assumed that the 7-meter high and 35-meter wide levee was destroyed at the collapse area shown in Fig. 5. If the stream's water level overflows through the collapsed levee, the inflow flood is calculated using eqn (1), assuming a rectangular weir equation. And the total amount of outflow that was calculated is used as input data for the SIMOD model and the Flo-2D model, and the time steps of the two models are the same

$$
\mathrm{Q}=\frac{3}{2} \mathrm{C} \cdot \mathrm{b} \cdot \sqrt{2 g} \cdot \mathrm{H}^{\frac{3}{2}}
$$

where $\mathrm{Q}$ refers to the flow rate $\left(\mathrm{m}^{3} / \mathrm{s}\right)$, C refers to the flow coefficient, $b$ refers to the width $(\mathrm{m})$, and h refers to the height $(\mathrm{m})$, and $\mathrm{C}$ has a range of 0.6 to 0.66 , and the average value of 0.63 is $1.85\left(m^{\frac{1}{2}}\right)$. If this is applied to eqn (1), it is equivalent to eqn (2)

$$
\mathrm{Q}=\mathrm{K} \cdot \mathrm{b} \cdot \mathrm{h}^{\frac{3}{2}}
$$

where $\mathrm{Q}$ refers to the flow rate $\left(\mathrm{m}^{3} / \mathrm{s}\right)$, K refers to the flow coefficient, $\mathrm{b}$ refers to the width (m), and h refers to the height $(\mathrm{m})$. Here, it was assumed that the approaching speed at the stream was ignored, and there was no change in the stream water level. The elevation at the upper end of the levee was $27.63 \mathrm{~m}$ (El.). Thus, considering the 7-meter high levee collapse scenario, the elevation at the lower end of the levee was $20.63 \mathrm{~m}$ (El.). A flood was introduced to the protected lowland over the entire simulation hours (100 hours). Fig. 6 shows the stream flood stage and inflow flood in the protected lowland according to the virtual scenario, and Table 1 presents the cumulative total outflow by time.

Currently, most studies employ DEM terrain data to analyze inundation. However, urbanization has increased due to the development of civilization, subsequently increasing the factors when analyzing flooding, such as impervious areas of building groups. In this study, existing DEM and DSM terrain data represented building groups and road distribution in urban areas and analyzed inundation in an urban region. The results of DEM and DSM terrain data are shown in Fig. 7. 


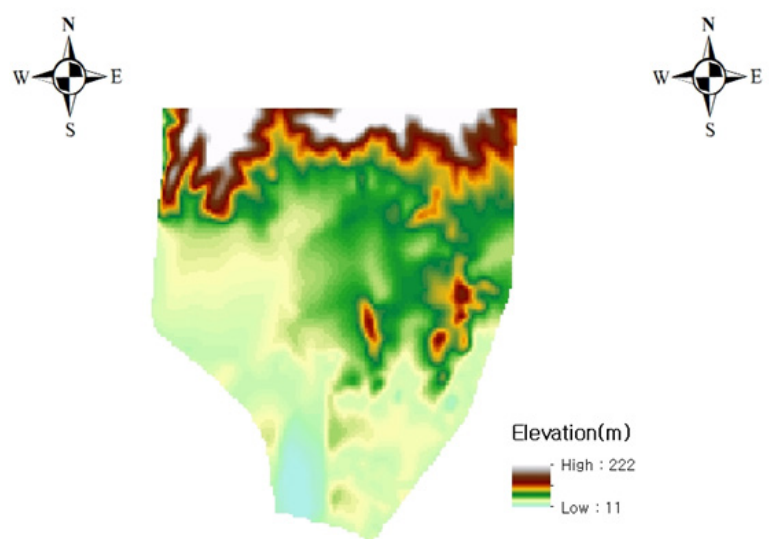

(a)

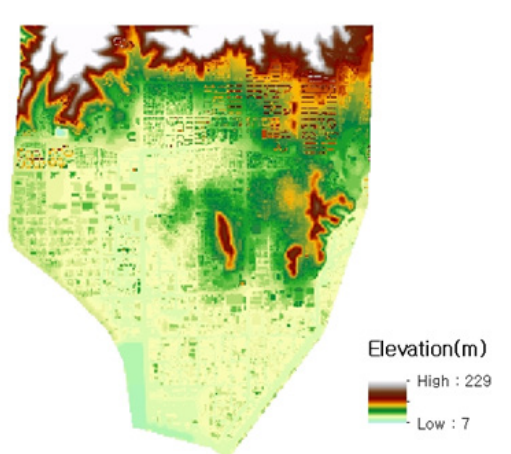

(b)

Figure 7: Terrain data (digital surface model, DSM). (a) DEM; and (b) DSM.

Table 1: Cumulative total outflow.

\begin{tabular}{|c|c|c|c|c|c|c|c|}
\hline $\begin{array}{c}\text { Time } \\
(\mathrm{hr})\end{array}$ & $\begin{array}{c}\text { Total outflow } \\
\left(\mathrm{m}^{3}\right)\end{array}$ & $\begin{array}{c}\text { Time } \\
(\mathrm{hr})\end{array}$ & $\begin{array}{c}\text { Total outflow } \\
\left(\mathrm{m}^{3}\right)\end{array}$ & $\begin{array}{c}\text { Time } \\
(\mathrm{hr})\end{array}$ & $\begin{array}{c}\text { Total outflow } \\
\left(\mathrm{m}^{3}\right)\end{array}$ & $\begin{array}{c}\text { Time } \\
(\mathrm{hr})\end{array}$ & $\begin{array}{c}\text { Total outflow } \\
\left(\mathrm{m}^{3}\right)\end{array}$ \\
\hline \hline 5 & $2,055,750$ & 30 & $36,406,264$ & 55 & $99,849,314$ & 80 & $154,357,400$ \\
\hline 10 & $6,133,322$ & 35 & $44,462,268$ & 60 & $117,492,331$ & 85 & $160,698,147$ \\
\hline 15 & $12,077,848$ & 40 & $52,536,904$ & 65 & $130,134,271$ & 90 & $166,652,328$ \\
\hline 20 & $19,036,509$ & 45 & $64,653,536$ & 70 & $139,754,559$ & 95 & $171,194,834$ \\
\hline 25 & $27,411,181$ & 50 & $82,179,722$ & 75 & $147,738,737$ & 100 & $175,585,297$ \\
\hline
\end{tabular}

\subsection{Analysis of inundation using DEM topographic data}

The analysis was conducted by applying the calculated outflow to the commonly used DEM. The results exhibited around a $10 \%$ flooded area difference, except for $38.7 \%$ of area difference during the first 60 minutes when the flood started. In addition, the inundation analysis time showed that the simulation execution time for 24 hours using the SIMOD model was 7 minutes, which verified that the analysis was fast.

\subsection{Analysis of inundation using DSM topographic data}

The flood path following the distributions of building groups and roads is essential when simulating an inundation analysis in urban areas. The inundation analysis was conducted using DSM terrain data to verify building groups and roads in the study area. The analysis results showed that the difference in inundated areas was around $20 \%$. The analysis results using DEM and DSM are shown in Tables 2 and 3. This result confirmed that DSM terrain data had an advantage that could verify urban areas' flood paths. Thus, the need to use DSM terrain data was demonstrated when conducting an inundation analysis in urban areas. Tables 4 and 5 show the difference in inundation area and runtime between two models. 
Table 2: Variation of inundation area (DEM).

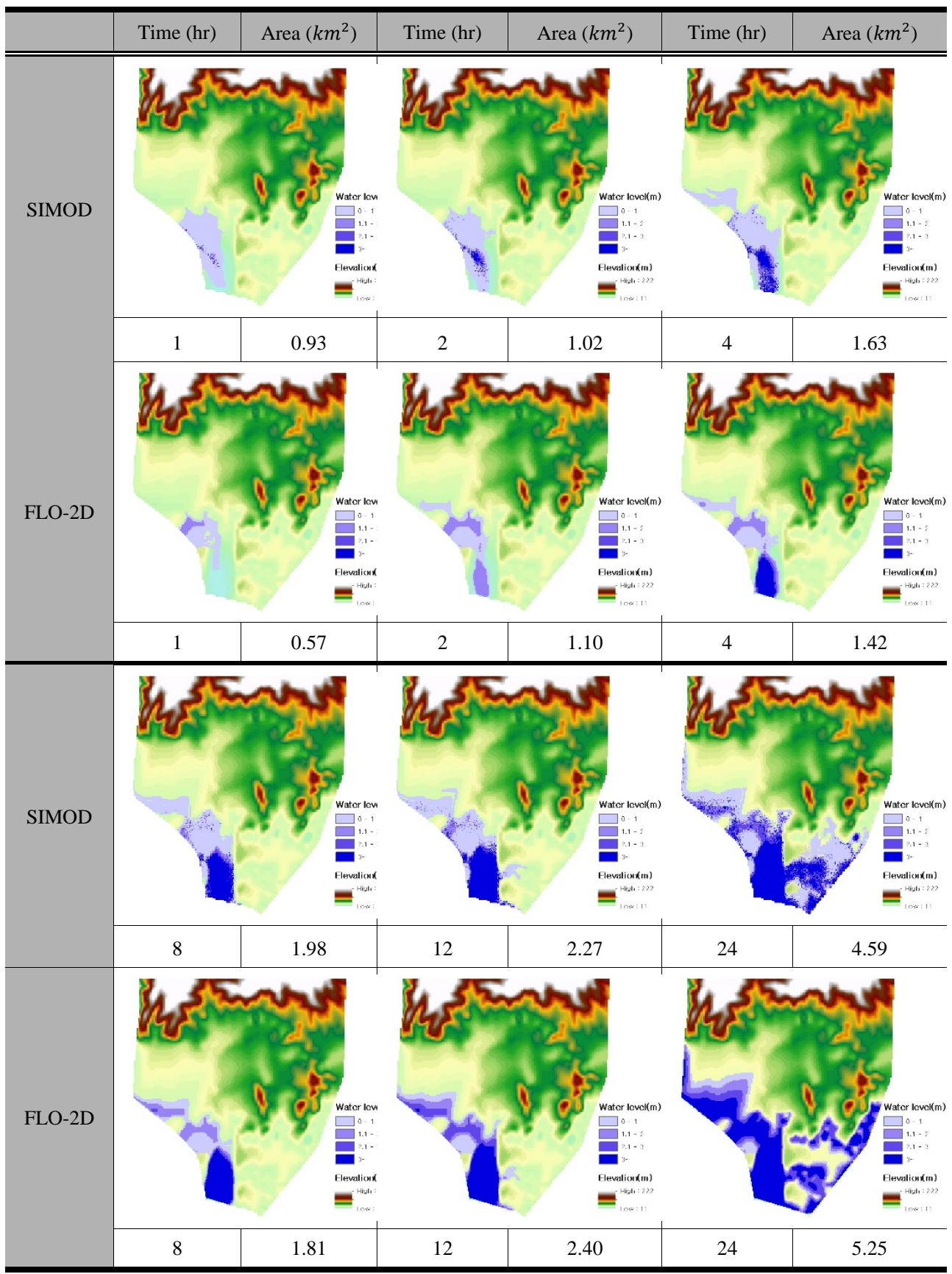


Table 3: Variation of inundation area (DSM).

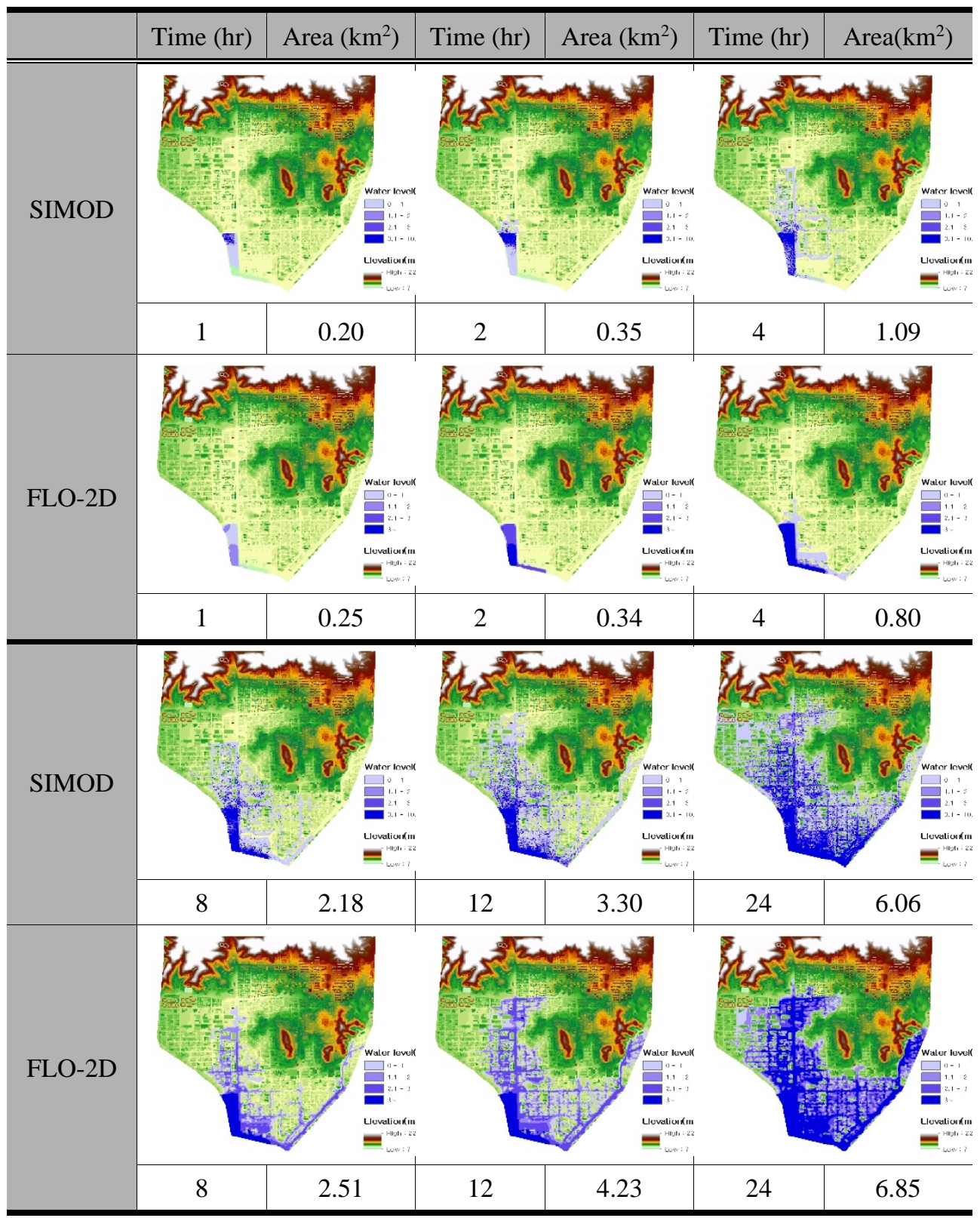


Table 4: Result of applying Simplified Inundation MODel (SIMOD) and two-dimensional flood routing model Flo-2D models using digital elevation model (DEM) data.

\begin{tabular}{c|c|c|c|c|c}
\hline & $\begin{array}{c}\text { SIMOD } \\
\left(\mathrm{km}^{2}\right)\end{array}$ & $\begin{array}{c}\text { SIMOD } \\
\text { run time }\end{array}$ & $\begin{array}{c}\text { FLO-2D } \\
\left(\mathrm{km}^{2}\right)\end{array}$ & $\begin{array}{c}\text { FLO-2D } \\
\text { run time }\end{array}$ & $\begin{array}{c}\text { Area } \\
\text { difference } \\
(\%)\end{array}$ \\
\hline \hline 1 & 0.93 & $1 \mathrm{sec}$ & 0.57 & $18 \mathrm{sec}$ & 38.7 \\
\hline 2 & 1.02 & $1 \mathrm{sec}$ & 1.10 & $42 \mathrm{sec}$ & 7.9 \\
\hline 4 & 1.63 & $10 \mathrm{sec}$ & 1.42 & $1.5 \mathrm{~min}$ & 13.2 \\
\hline 8 & 1.98 & $30 \mathrm{sec}$ & 1.81 & $4 \mathrm{~min}$ & 8.7 \\
\hline 12 & 2.27 & $2 \mathrm{~min}$ & 2.40 & $10 \mathrm{~min}$ & 5.8 \\
\hline 24 & 4.59 & $7 \mathrm{~min}$ & 5.25 & $25 \mathrm{~min}$ & 14.3 \\
\hline
\end{tabular}

Table 5: Result of applying Simplified Inundation MODel (SIMOD) and two-dimensional flood routing model Flo-2D models using digital surface model (DSM) data.

\begin{tabular}{c|c|c|c}
\hline & SIMOD $\left(\mathrm{km}^{2}\right)$ & FLO-2D $\left(\mathrm{km}^{2}\right)$ & Area difference (\%) \\
\hline \hline 1 & 0.20 & 0.25 & 26 \\
\hline 2 & 0.35 & 0.34 & 4.8 \\
\hline 4 & 1.09 & 0.80 & 26.6 \\
\hline 8 & 2.18 & 2.51 & 15.4 \\
\hline 12 & 3.30 & 4.23 & 28 \\
\hline 24 & 6.06 & 6.85 & 12.9 \\
\hline
\end{tabular}

5 CONCLUSION

This study aimed to verify the applicability of SIMOD, a distributed flood routing model that could support decision-making by analyzing urban inundation quickly. SIMOD was a simplified model of many complex hydraulic and hydrologic algorithms required for the urban inundation analysis into two outflow distribution method algorithms: MFDM and FWA. This study aimed to analyze the applicability of the results obtained with the minimum analysis time. Thus, this study compared the analysis results with those using the commercial FLO-2D model. The comparative analysis results were as follows:

1. The flood analysis results using SIMOD and FLO-2D models verified that SIMOD took a shorter time to analyze inundation than FLO-2D. SIMOD took around seven minutes for a 24-hour simulation, whereas FLO-2D took approximately 25 minutes. Even considering the initial input time, SIMOD could take 10 minutes for a 24 -hour inundation analysis.

2. The model analysis results using the DEM terrain data exhibited that the error rate of the inundated area between the SIMOD and FLO-2D models averaged around 20\%. Because this was flood routing using the total inflow for the fast analysis of SIMOD, 
there would be a difference in the degree of error. Nonetheless, sections that exceeded the error rate of $20 \%$ meant a difference in the model precision, requiring the future improvement of SIMOD.

3. The model analysis results using DSM terrain data verified that the interference by facilities, such as building groups and roads in the urban region, were expressed. This verification could not be done using DEM terrain data, and the flood routing path over time could be reflected correctly according to the actual topography.

\section{ACKNOWLEDGEMENT}

This work was funded by the Korea Meteorological Administration Research and Development Program under Grant KMI [2021]-[000312].

\section{REFERENCES}

[1] Kim, B. \& Ha, S., The impact assessment of climate change on design flood in Mihochen basin based on the representative concentration pathway climate change scenario. Journal of Wetlands Research, 15(1), pp. 105-114, 2013.

[2] Jeung, S., Lee, S. \& Kim, B., Nonstationary intensity-duration-frequency curves under climate change. Korea Water Resources Association, 2015.

[3] Lee, J., Jeon, W. \& Hur, S., Analysis of inundation characteristics for EAP of highway in urban stream - Dongbu highway in Jungrang stream. Korean Society of Hazard Mitigation, 6(3), pp. 69-76, 2006.

[4] Yang, T.-H., Chen, Y.-C., Chang, Y.-C., Yangand, S.-C. \& Ho, J.-Y., Comparison of different grid cell ordering approaches in a simplified inundation model. Water, 7, pp. 438-454, 2015.

[5] Syme, W.J., Pinnell, M.G. \& Wicks, J.M., Modelling flood inundation of urban areas in the UK using 2D/1D hydraulic models. The Institution of Engineers, Australia 8th National Conference on Hydraulics in Water Engineering, 2004.

[6] Pathirana, A., Tsegaye, S., Gersonius, B. \& Vairavamoorthy, K., A simple 2-D inundation model for incorporating flood damage in urban drainage planning. Hydrology and Earth System Sciences, 15, pp. 2747-2761, 2011.

[7] Nanshan, Z., Yasuto, T. \& Kaoru, T., Simplified flood inundation model integration with rainfall-runoff processes. Annuals of Disaster Prevention Research Institute, Kyoto University, $\mathbf{5 0}$ pp. 75-78, 2007.

[8] Yang, T.H., Chen, Y.C., Chang, Y.C., Yang, S.C. \& Ho, J.Y., Comparison of different grid cell ordering approaches in a simplified inundation model. Water, 7(2), pp. 438-454, 2015. DOI: 10.3390/w7020438.

[9] Liu, L. et al., Developing an effective 2-D urban flood inundation model for city emergency management based on cellular automata. Natural Hazards and Earth System Sciences, 15, pp. 381-391, 2015.

[10] Jeon, M., Han, D. \& Choi, K., Flood inundation analysis from levee failure in Nakdong river. Korea Water Resources Association, 38(4), pp. 259-269, 2005.

[11] Lee, J.H. \& Yeon, K.S., Flood inundation analysis using XP-SWMM model in urban area. Korean Society of Hazard Mitigation, 8(5), pp. 155-161, 2008.

[12] Lee, J.T., Hur, S.C., Kim, J.H. \& Han, K.Y., Characteristics of the inundation and process of making a flood Map according to the levee break conditions in urban stream - Jungrang experimental basin. Journal of the Korea Water Resources Association, 39(5), pp. 383-394, 2006.

[13] Park, J., Han, K. \& Ahn, K., Development of numerical model to analyze levee break. Korea Water Resources Association, 38(4), pp. 259-269, 2009. 
[14] Kim, B.H., Choi, S.Y. \& Han, K.Y., An analysis method of 1D hydrodynamic model based on GIS for flood inundation mapping. Korean Society of Hazard Mitigation, 11(6), pp. 227-235, 2011.

[15] Kim, D.H., Jang, D.W., Park, H.S. \& Choi, G.W., A study on flood impact upon the downstream area of a river by Dam break. Crisis and Emergency Management: Theory and Praxis, 10(2), pp. 117-132, 2014.

[16] Tarboton, D.G., A new method for the determination of flow directions and upslope areas in grid digital elevation models. Water Resource Research, 33(3), pp. 9-19, 1997.

[17] Ministry of Land, Infrastructure and Transport, Kumho River Maintenance Basic Plan, 1997. 